\title{
THE ROUTE MOST TRAVELED: THE AFAR SALT TRAIL, NORTH ETHIOPIA ${ }^{1}$
}

\author{
LA RUTA MÁS TRANSITADA: EL SENDERO DE LA SAL DE AFAR, \\ NORTE DE ETIOPÍA
}

\author{
Helina S. Woldekiros ${ }^{2}$
}

In Africa and elsewhere, scholars have demonstrated that early social, political, and economic structures were shaped by salt production, distribution, and long-distance trade in areas where salt was a critical resource. However, despite salt's significant role in developing these structures, archaeological studies of the salt trade have focused almost exclusively on artifacts and historical text references. As a result, data on the diverse and complex routes through which this important commodity has traveled and the nature of its transportation are lacking. This paper examines evidence of ancient Aksumite (400 BC-900 AD) salt trade and exchange from the lowland Ethiopian deserts to the North Ethiopian and Eritrean highlands, drawing on recent ethnoarchaeological and archaeological fieldwork conducted in the Danakil Desert and Aksumite towns. The data reveal that the Afar salt trail passes through diverse regional ecozones, highland trader towns, and foothill towns, via several highland routes and one major lowland route. The study shows that caravaners followed the least costly path on the highland portion of the route, with ideal slopes for pack travel and plentiful water sources. The study also describes ancient caravan campsites dating to ca. 5th century CE and shows that participants differed in religion and identity.

Key words: Salt caravan, Aksumite trade, Africa, ethnoarchaeology.

\begin{abstract}
En África como en otros lugares, los investigadores han demostrado que estructuras políticas, sociales y económicas tempranas fueron moldeadas por la producción de sal así como por su distribución y comercio de larga distancia en áreas donde la sal era un recurso crítico. Sin embargo, a pesar del importante rol de la sal en el desarrollo de estas estructuras, los estudios arqueológicos del comercio de sal se han centrado casi exclusivamente en artefactos y referencias a textos históricos. Como resultado, hacen falta datos acerca de las diversas y complejas rutas a través de las cuales esta importante mercancía ha viajado así como de la naturaleza de su transporte. Este trabajo examina evidencia del comercio e intercambio de sal en el antiguo Aksum (400 AC-900 DC) desde las tierras bajas de los desiertos de Etiopía hasta las tierras altas del norte de Etiopía y Eritrea, a partir de trabajo de campo arqueológico y etnoarqueológico reciente llevado a cabo en el desierto de Danakil y pueblos aksumitas. Los datos revelan que el camino de sal de Afar atraviesa diversas ecozonas regionales, pueblos comerciantes de las tierras altas, y pueblos de las laderas, por medio de varias rutas de las tierras altas y una ruta principal en las tierras bajas. El estudio muestra que los caravaneros seguían el camino menos costoso en la porción de la ruta ubicada en las tierras altas, con pendientes ideales para viajes en manada y abundantes fuentes de agua. El estudio también describe campamentos caravaneros antiguos que datan alrededor del siglo V de la era cristiana y muestra que los participantes diferían en términos de religión e identidad.
\end{abstract}

Palabras claves: caravana de sal, comercio aksumita, África, etnoarqueología.

The multi-faced nature of salt as a primary food condiment, a physiological necessity, and an object of trade has made it a valuable commodity for humans worldwide. In Africa as well as in other parts of the world, scholars have demonstrated that social, political, and economic structures have been shaped by salt production, distribution, and long-distance trade in areas where salt has been a critical resource (BarrettGaines 2004; Connah 2001; Connah et al. 1990; Good 1972; Lovejoy 1984; McDougall 1990). The significance of caravan trade in salt is well known in Africa. Historical research on the salt trade at Ijil in the

\footnotetext{
${ }^{1}$ An earlier version of this article was presented at the International Workshop "Caravan Archaeologies: En Route to the Past, Present and Future", Pica, Chile (May 2017). This manuscript was evaluated by external reviewers and edited by the Chungara Editorial Committee and the invited editors Persis B. Clarkson and Calogero M. Santoro.

2 Department of Anthropology, Washington University in St. Louis, Campus Box 1114, One Brookings Drive, St. Louis, MO 63130, USA., hswoldek@wustl.edu
} 
Sahara has demonstrated that trade extended 5,000 $\mathrm{km}$, from northwestern Mauritania to Sudan. This facilitated the economic growth and political strength of complex ancient societies in the Sahara by connecting communities and moving commodities that would have otherwise been unobtainable without the common demand for salt (Lovejoy 1986; McDougall 1990).

Because salt is ephemeral, studies of the salt trade at Ijil and other places have focused on artifacts and historical texts and inscriptions. Researchers have also focused on the study of salt extraction areas, rather than trails, because such areas preserve artifacts such as ceramics used for salt evaporation and transport (Alexianu and Weller 2009; Harding 2013; Williams 1999). Only a few studies have focused on the organization of ancient salt trade routes; such studies have highlighted the reconstruction of salt trade routes as lines on the landscape, emphasizing the people and places mentioned in historical texts (Brigand and Weller 2015). In Africa, data on the diverse and complex routes and contexts through which commodities have traveled and the nature of their transportation are lacking. As a result, we have an incomplete understanding of the different participants on such routes, the places they have called home, the passes they have used, and their daily, monthly, and yearly itineraries. Therefore, ethnoarchaeological studies of salt caravan transport can contribute a great deal to developing our understanding of ancient salt trade routes and itineraries in Africa.

In this paper, I focus on the Afar salt trail, which is today one of the most actively traveled pack-based caravan routes in the world. The trail starts over $2,000 \mathrm{~m}$ above sea level, in the North Ethiopian highlands, and drops to $200 \mathrm{~m}$ below sea level in the low deserts of the Afar, covering a distance of about $160 \mathrm{~km}$ (Figure 1). Approximately 70,000 animals, carrying 10,000 to 20,000 tons of salt, travel the Afar trail each year (Wilson 1976; Woldekiros 2014). Caravans of highland farmers and lowland mobile pastoralists follow the route to retrieve salt from Lake Asale (Lake Karum) — a major source of salt in the Danakil Depression. This salt is then distributed to the densely populated and agriculturally rich Ethiopian highlands. In both historic and modern times, salt from the Afar depression has traveled beyond the borders of Ethiopia, all the way to Sudan and Yemen. Today, approximately $72 \mathrm{~km}$ of the trail is traveled by pack animal caravans, just as was done in the Medieval period (Wolska-Conus 1962), according to 6th century texts that mention the use of the trail as early as the Aksumite period (400 BC-900 AD). Recent archaeological investigations on the Afar trail have also revealed the presence of Aksumite caravan camps and trader and logistical towns along the route (Woldekiros 2014). In this paper, I present the results of an excavation of two ancient caravan campsites that were discovered along the route. The first was found near the highland portion and the second was found in the transition zone between the highlands and the lowlands. These sites are compared to contemporary caravan sites in an attempt to model the materiality of ancient and modern caravan campsites and salt trail.

The study also highlights the complexity of the Afar salt trail in terms of its shape, altitudes, temperatures, and favorable passes between the highlands and lowlands, as well as the differing pack animal preferences between highland and lowland caravaners (with the former preferring donkeys and the latter preferring camels). The modern and ancient trail passes through diverse regional ecozones, highland trader towns, and foothill towns (Woldekiros 2014), but GIS analysis suggests that, on the highland portion of the route, caravaners seek to follow the least costly path. The study also reveals that cultural identity, a gendered division of labor, seasonality, and economic mobility shape activity along the trail. In following sections, I discuss the operation and visibility of the trade route on the landscape.

\section{Caravan Ethnoarchaeology}

Ethnoarchaeological study of caravans is useful for deepening our understanding of trade in consumable goods as well as the participation of multiple agents in local trade. Ethnographic studies of caravans can answer important anthropological questions regarding the role of the elite and non-elite in the organization of trade, the role of trade in structuring relationships between cultural groups, and the development of complex social institutions. In particular, caravan ethnoarchaeology has been useful for studying the mechanisms of ancient exchange, trade, and transport, and for identifying the material traces of ancient trade in Egypt and the Andes (Berenguer 2004; Falola 1991; Förster 2007; Nielsen 2001; Smith 2005; Tripcevich 2008, 2016). In the Andes, caravan trade has been found to be an important livelihood of highland llama and alpaca herders (Clarkson et al. 2017; Nielsen 2001; Valenzuela et al. 2018). Furthermore, both contemporary and ancient Andean caravan trade has been shown to be interlinked with ideology, economics, and politics (Tripcevich 2016; Valenzuela et al. 2018). Detailed archaeological research conducted on the Abu Ballas caravan trail in Egypt provides a lowland caravan counterpart to these findings. The trail, dating to $2190 \pm 30 \mathrm{Cal} \mathrm{BC}$ (KIA2068 3, -20684), extended from the Dakhla Oasis in Egypt's Western Desert to the Gilf Kebir plateau in the Libyan Desert, and provides evidence of a $400 \mathrm{~km}$ Old Kingdom donkey caravan route linking the Egyptian state to the Sudanese region (Förster 2007:6). This route enabled access to tropical resources that were desired by the Egyptians and bypassed the narrow and easily controlled Nile Valley (Förster 2007). Staging posts, 


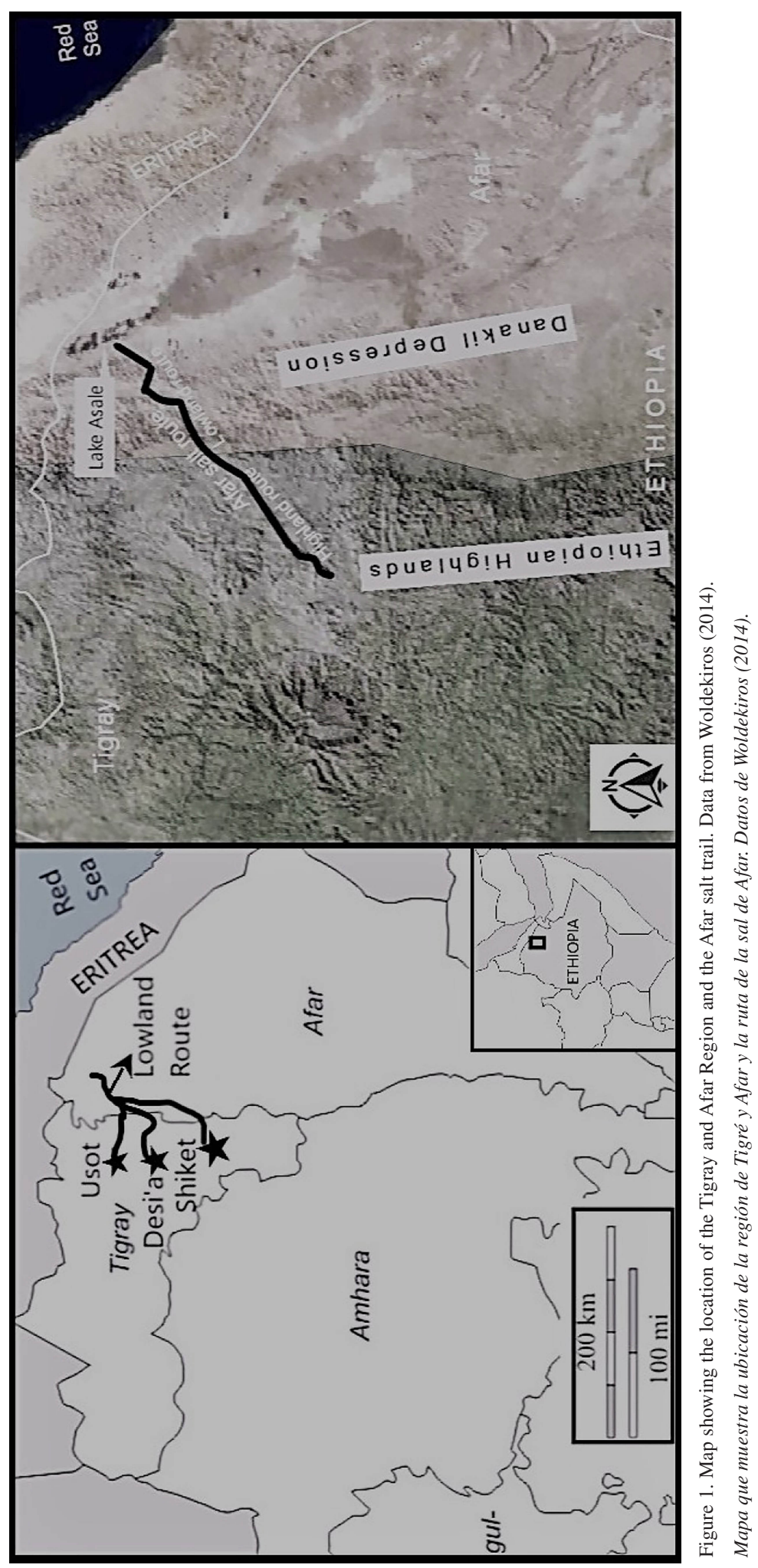


stone cairns, and small circular stone structures were used to identify the ancient trails and their travelers, and ceramic pots were deployed at each staging post to provide food and water for travelers and their donkeys. This route is considered to have been under state control. Förster (2007) used ceramic data to date the trail and to identify the staging posts and regional identities of the traders. Förster et al. (2013) note, however, that without ethnographic data on donkey caravans, the length of time spent on the trail and the costs of transport are difficult to estimate.

Biginagwa's (2012) caravan-based archaeological research at a $19^{\text {th }}$ century site in Tanzania also demonstrates the utility of this approach. His study showed that caravans have a transformational effect on the regions through which they pass. Biginagwa (2012) documented, for example, the intensification of the production of subsistence goods in caravan towns. Caravan trade studies of this kind can be excellent indicators of the direct transport of goods versus indirect exchange, and of the complex organization of trade. In this way, they contribute to bodies of data that bear on the complexity of ancient economies.

Having discussed some key aspects of caravan archaeology and ethnoarchaeology, in the following section, I provide background information on the Aksumites. This information will serve as the context for my inquiry into ancient salt trade on the Afar salt route.

\section{Background}

The ancient Aksumite state of the North Ethiopian and Eritrean highlands was the most powerful state in sub-Saharan Africa from 400 BC-900 AD (Figure 2). The Aksumites were participants in the ancient Egyptian and Roman Red Sea trade, and at one point were considered a rival empire by the Romans (Finneran 2007; Munro-Hay 2002; Phillipson 2012). The Aksumites were expansionists, and at the height of their power they controlled a portion of modern-day Sudan and South Yemen (Finneran 2007; Phillipson 2012). The wealth and expansion of the Aksumite state have been tied to participation in ancient global trade, as well as their highland agricultural way of life (Phillipson 2000). The Aksumites engaged in extensive farming, including the domestication of t'ef (the world's smallest grain, used to make bread and beer) (D'Andrea 2008; Lyons and D'Andrea 2003; Mercuri et al. 2018). Cattle keeping was also an important source of Aksumite wealth. Prior to this project, however, very little was known about the role of local trade in salt in Aksumite wealth and power creation.

The location of the Afar salt source in the harshest and hottest desert terrain, as well as the physiological requirement of salt for the Aksumite's agricultural way of life, would have motivated the Aksumites to

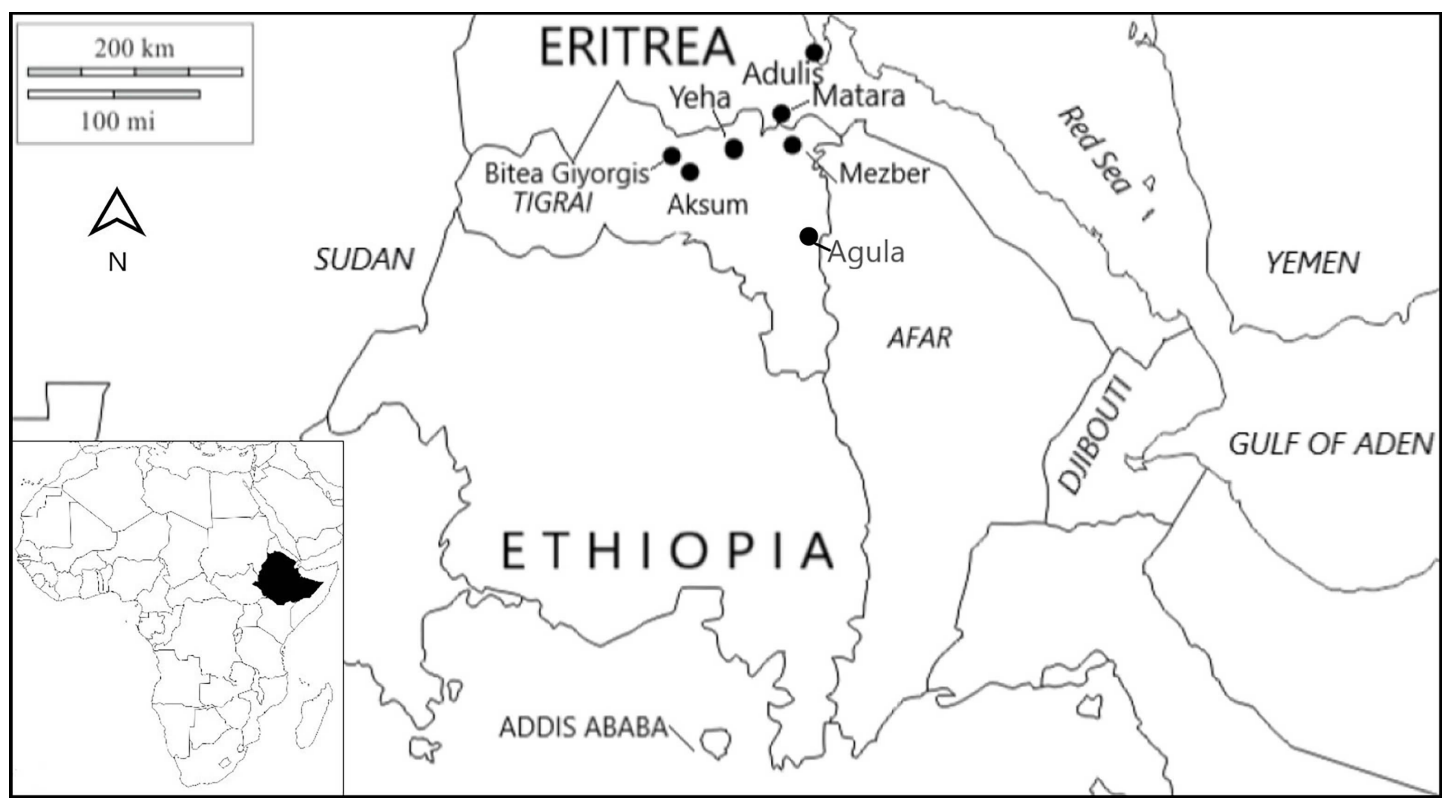

Figure 2. Ancient Aksumite sites.

Antiguos sitios Aksumitas. 
acquire salt in bulk from the Danakil Depression. In fact, salt would have been an essential commodity in the Ethiopian highlands over the past 5,000 years, not only as a supplement to the plant-based diet but also as a cattle lick to support lactation.

Until recently, research has concentrated on merely describing the long-distance trade route and the participation of the Aksumites on this route (Harrower and D'Andrea 2014). Considering the role of the Aksumites as an important player in Red Sea trade with the major powers of the time (including the Egyptians, Romans, and Persians) and the presence of exotic materials at Aksumites sites, it is only natural to focus on the long-distance trade route. Description of this trade route comes not only from archaeological sites, but also historical texts (Munro-Hay 2002; Phillipson 2012).

\section{Materials and Methods}

\section{Ethnoarchaeological study}

I employed participant observation, interview, and photographic documentation methods to characterize the route and describe its participants. I also used GPS points to map the present-day salt route and to reconstruct possible ancient salt caravan routes. I rented camels and donkeys and joined caravaners on the highland and lowland portions of the route, walking with them on the trail. In total, I collected data from 158 caravaners: 117 from the highlands and 41 from the lowlands. Amongst them, they had 196 donkeys, 11 mules, and 566 camels. Information was collected on caravaner identities, itineraries, logistical support systems, logistical requirements, pack animal travel speeds (both with and without loads), distances traveled, preferred routes of travel, rest areas, end points, and watering places.

\section{Archaeological study}

In order to date the route and identify ancient sites associated with it, inventory style survey and excavation were conducted in $10-\mathrm{km}$ stretches of the route, covering $500 \mathrm{~m}$ in total on each side (highland and lowland). In particular, three contexts were examined: flat lands at the highland trail head, where contemporary caravaners camp before descending into the lowlands; a 25-km section of a low altitude flat land trail, near the salt extraction areas; and the lowland trail head, where caravaners camp.

Using a stratified sampling strategy, excavation sites from the three contexts were selected on the basis of the survey results, and test excavation was conducted in two ecological zones. In total, two ancient caravan campsites were excavated: Meda Ble'at (unit 2) at the town of Agula (a highland border town) and Ona Adi Abobay (unit 1) at Desi'a (a foothill town). Unit 2 measures $2 \times 2 \mathrm{~m}$ and is situated on top of a natural levee. Unit 1 measures $3 \mathrm{x}$
$3 \mathrm{~m}$ and is located $500 \mathrm{~m}$ west of the local river and $100 \mathrm{~m}$ north of a major caravan route used by both Tigray and Afar caravaners traveling to and from the salt flat (Figure 2). Ona Adi Abobay is in a key location, close to the last campsite before descending from the highlands and the first campsite when returning from the salt flat. This is a transitional site that adjoins the highland and lowland portions of the salt trail, and has been used since the Aksumite period by both highland and lowland caravaners.

Sediments were screened through $5 \mathrm{~mm}$ and $1.5 \mathrm{~mm}$ fine mesh screens and collected under a single provenience designation. The $1.5 \mathrm{~m}$ mesh screen was used only in the northeast quadrant of each unit, to collect control samples. The chronology of the caravan campsites was determined by associating pottery with stratigraphic archaeological layers. All of the sites demonstrated Aksumite and Medieval period occupation phases.

\section{The Study Area: Physical Geography and Environmental Context}

The Afar salt route passes through two dynamic ecological zones: highlands and lowland deserts. The northern Ethiopian highlands, located immediately west of the Danakil Depression, were the hub of the Aksumite and Medieval Ethiopian state (Figure 3). They are characterized by massive plateaus and steep escarpments, which were formed by extrusions of basaltic lavas and displacements along fault lines (Behrens 1971). The Ethiopian escarpment is $3,000 \mathrm{~m}$ above sea level and made up of trap rocks underlain by Mesozoic sandstone (EGS 1973:53). The north escarpments tend to trend northwest, while the south escarpments tend to have blocks warped south towards the depression.

A large portion of the area is covered by highlands reaching up to 2,000 $\mathrm{m}$ above sea level, but the highlands are composed of different blocks of varying altitudes. The extreme relief variation over short distances has resulted in a wide range of climates, vegetation, and soil types, leading to the classification of Ethiopia into five major climatic zones: wirch (alpine 3,500+), dega (temperate 3,500-2,500), weina dega (subtropical 2,500-1,800), kola (tropical 1,800-1,500), and bereha (desert below 1,500) (Behrens 1971). The extreme local relief makes communication and land transport very costly, unless pack animals are used.

During the Holocene, the Ethiopian highlands were forested. However, over the past 2,000 years, a great portion of the highland forest has been destroyed (Butzer 1981). The Ethiopian forests vary according to the five major climatic zones mentioned above, and forests now grow only in the weina dega, dega, and wirch zones. The highland portion of the salt route follows a silty clay soil, gravelly paths, and grasslands (Figure 4).

The lowland portion of the Afar trade route and the salt pan are found in the Afar desert, which is characterized by 


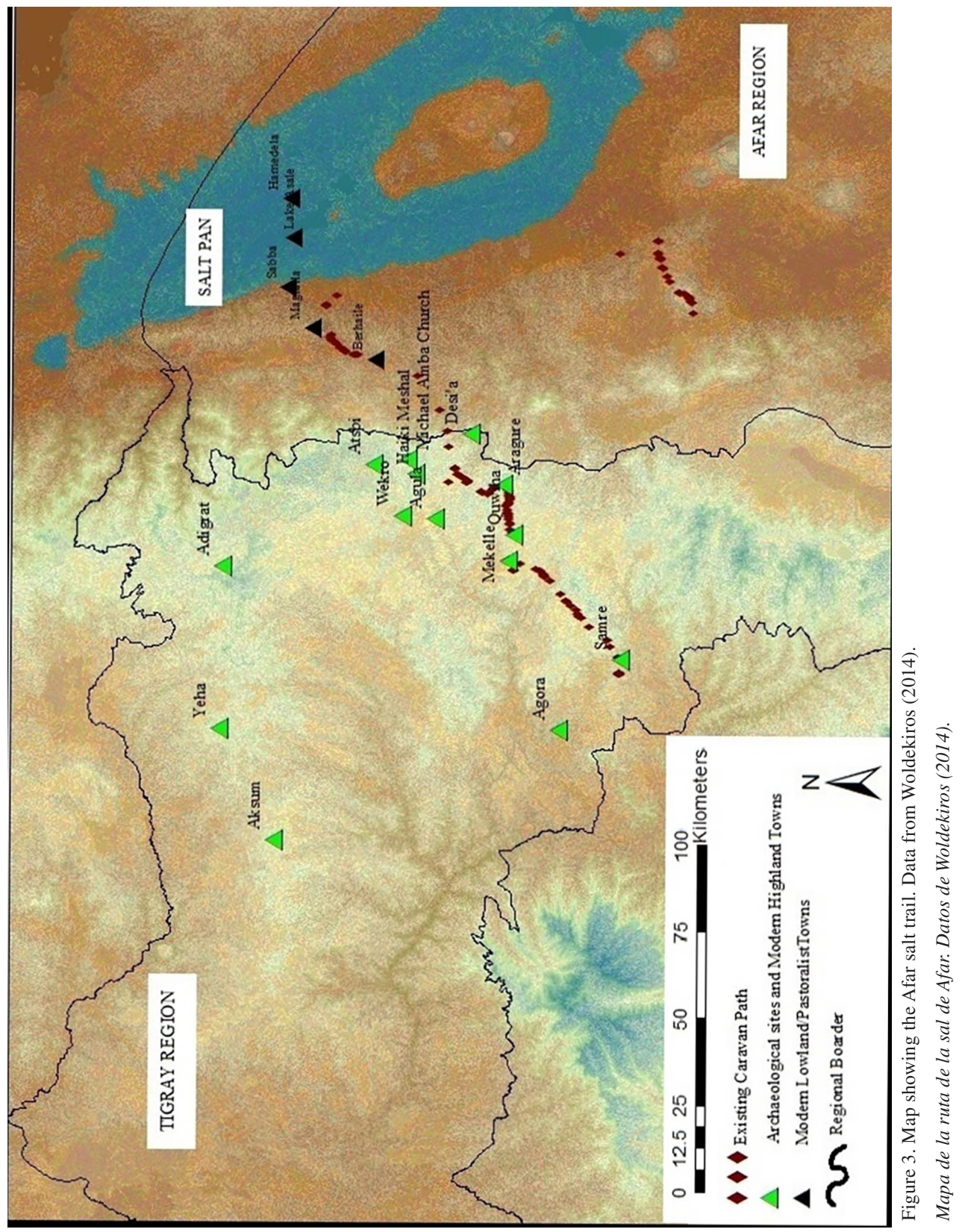




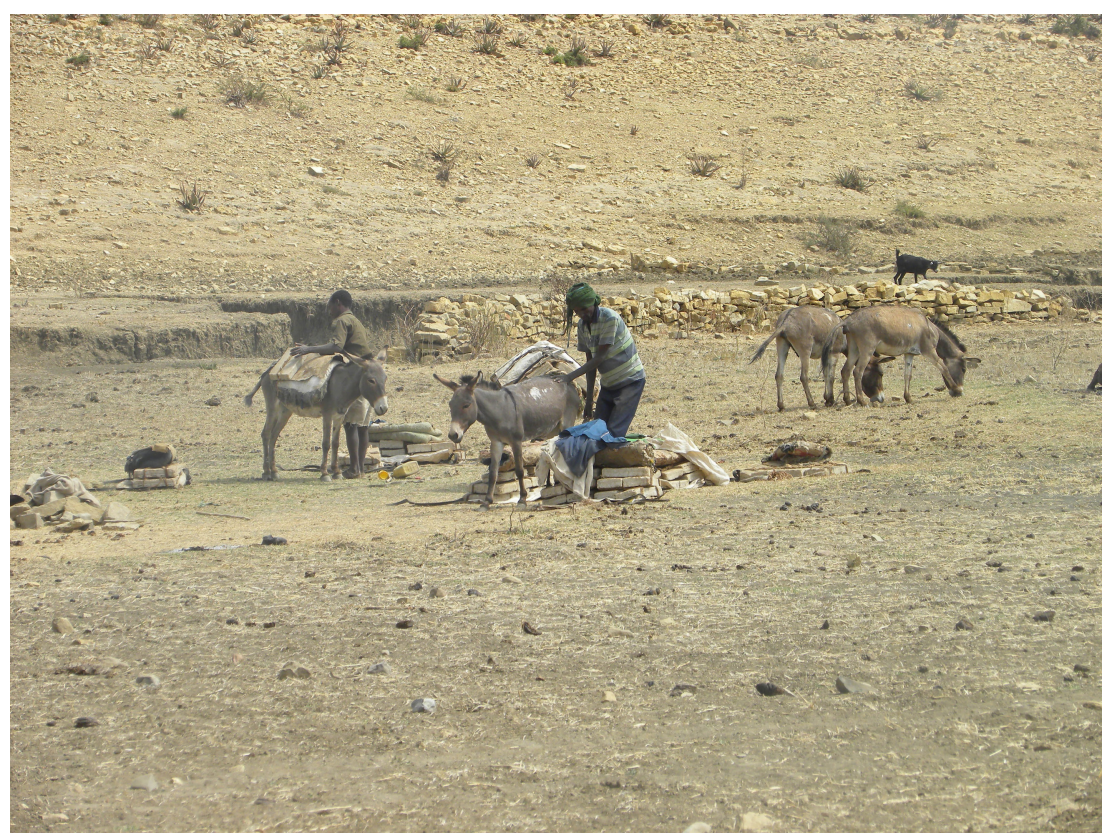

Figure 4. Highland portion of the salt route, silty clay soil, gravelly paths, and grasslands. Photo by Woldekiros (2014).

Porción de las tierras altas de la ruta de la sal, suelo de arcilla limosa y pastizales. Fotografía de Woldekiros (2014).

below-sea deserts, volcanos, craters, and high escarpments. The desert temperature is very harsh, reaching $140^{\circ} \mathrm{F}$ in the summer and $123^{\circ} \mathrm{F}$ in the winter (Bonatti et al. 1971). The Afar desert is located in the Danakil Depression, which forms part of the Ethiopian Rift Valley—a unique geological formation at the junction of the Ethiopian Rift, the Red Sea Rift, and the Gulf of Aden Rift. The Ethiopian Rift Valley is $1,000 \mathrm{~km}$ long and oriented in a north-northeast direction. The Afar Depression has seen successive volcanism since its formation. Absolute dating of the depression has shown that the final desiccation took place between 32,000 and 8,000 years ago (Bonatti et al. 1971; EGS 1973:54). As a result of the unique geologic formation, caravaners traveling through the Afar desert encounter different types of landscapes, including dense gravel, sand or fine-grained river sediment, and pebbly dry river beds (Figure 5). The last portion of the lowland route, about $7 \mathrm{~km}$, is rugged, wet sandy plain (Figure 6).

\section{Results}

\section{The route}

Overview

The Afar salt trail passes through diverse regional ecozones, highland trader towns, and foothill towns. In the highlands, favorable trails can be distinguished by suitable terrain for foot and pack animal travel. The trails I found followed rivers and streams, and appeared in high density in the Enderta district (Figure 7). Here, the river valleys are more advantageous as a path than a source of water, itself. Such valleys are good for navigating through steep areas and they help caravaners find the best slopes or terrain for pack animal travel. Water sources are easy to find in the highlands because, after the rainy season, the run-off coming from the western plateaus and hills gets trapped in riverbed pockets. However, in order to avoid flash floods and dehydration, caravaners must travel when water levels are not high, but also when rivers are not completely dry.

In the lowlands, caravaners follow the optimal path because they are aware of the long distance and the limited water sources available to them. It is likely that the lowland portion of the route may be exactly the same route as was once used by ancient caravaners, because there are very few alternative options for travel. Unlike the highlands, the lowlands have very limited water supplies; this has been the case for thousands of years.

\section{Highland route}

There are three major routes in the highlands that caravaners take to the lowlands: the Desi'a route (Route 1), the Usot route (Route 2), and the Shiket route (Route 3) (Figure 8). The Usot route is traveled by only a few caravaners - usually those from the Atsbi 


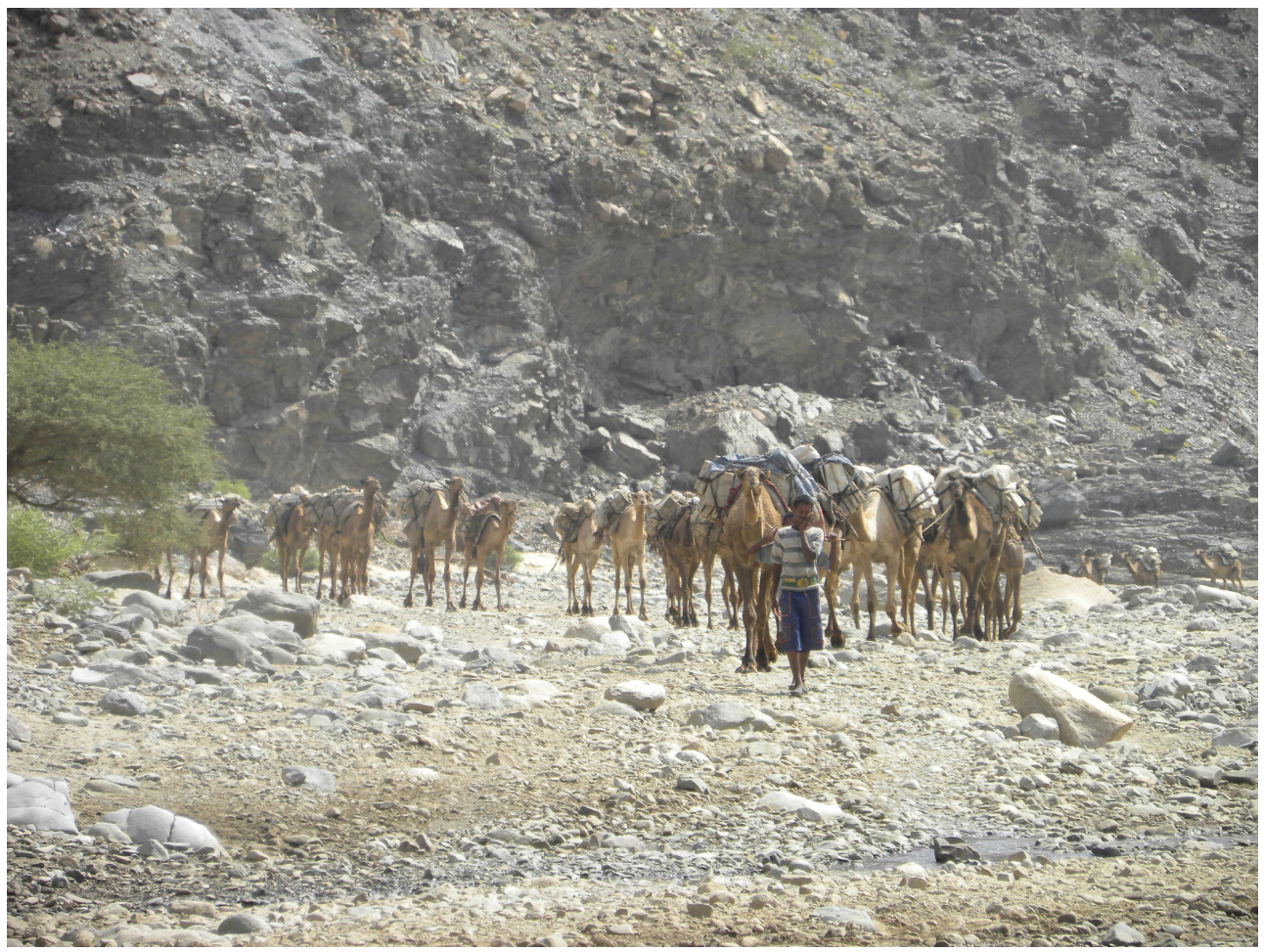

Figure 5. Lowland trail inside pebbly dry river bed. Photo by Woldekiros (2014).

Camino en las tierras bajas en un lecho de río pedregoso y seco. Fotografía de Woldekiros (2014).

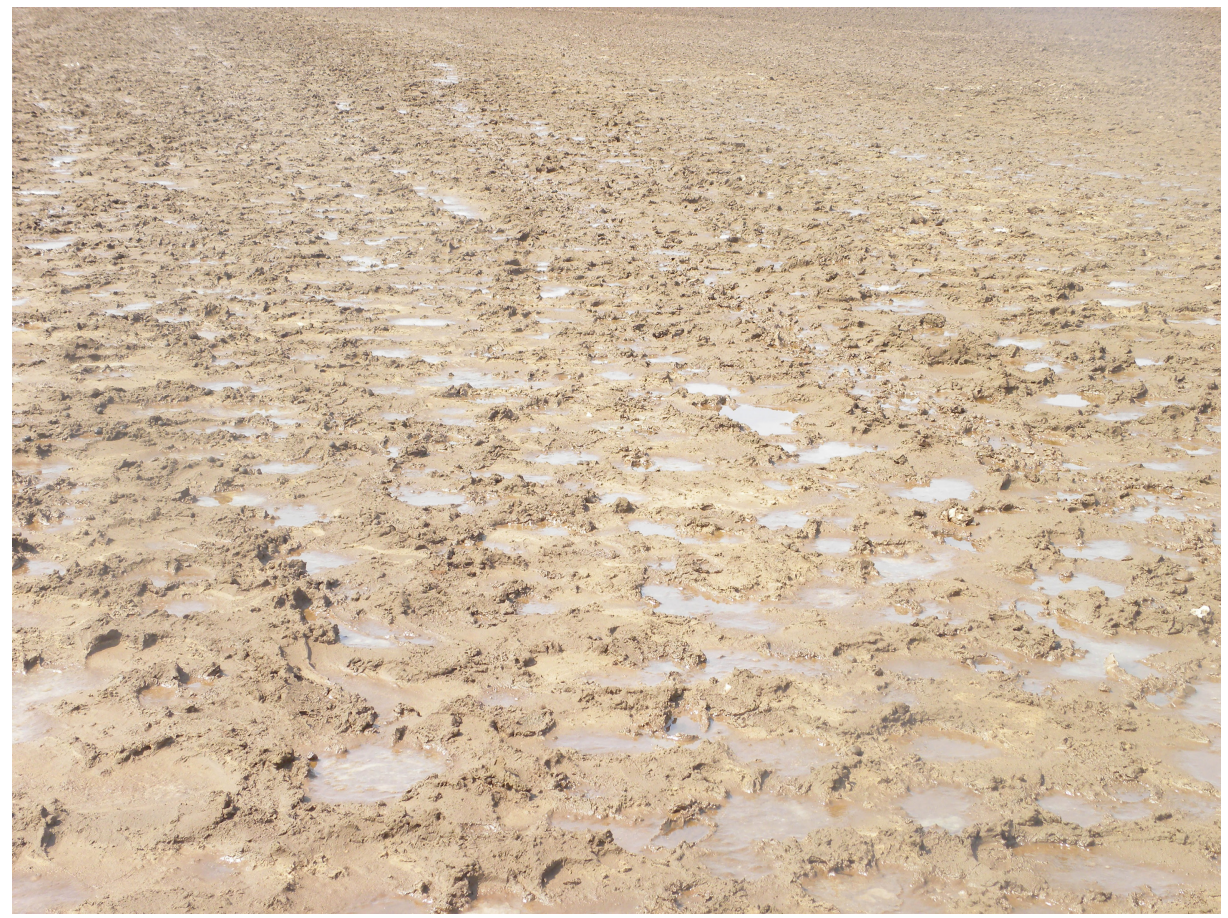

Figure 6. Last portion of the lowland route, rugged, wet sandy plain. Photo by Woldekiros (2014).

La parte final de la ruta en las tierras bajas, planicie arenosa y húmeda. Fotografía por Woldekiros (2014). 
Wonberta district in Eastern Tigray. The Usot route, in the lowlands, passes through the towns of Dalgena, Korha, Darguni, Berhaile, Melabdi, Asabolo (Sabba), and Hamed Ela, before reaching the salt flat (Reged).

The Desi'a route is the route most frequently traveled, and it lies between the northern and southern routes. Caravaners from the towns of Mekelle, Semere, Quhia, Raya Azebo, Gijet, and Temben follow this route, which crosses the lowlands through Desi'a, Korha, Darguni, Berhaile, Melabdi, Asa Bolo (Sabba), and Hamed Ela, before ending at the salt flat. This route is primarily used by caravaners who live in Central and Southern Tigray.

The third—or Shiket—route is an optional route that crosses the lowlands through a pass located in Shiket. This pass can be used when pasture is available, but it is usually too hot for travelers exiting the highlands. However, the landscape on this route is flat and especially favorable for camel caravans. Shiket lies $28 \mathrm{~km}$ south of Desi'a, at an elevation of 1,350 m above sea level.

According to my interviewees, it takes most highland caravaners 14 to 15 days to travel from their home to the salt flat, but it can take 7 to 10 days to traverse each way. Highland caravaners make an average of 14 trips per year to the salt flat. If the group decides to make two trips from the salt flat to the lowland town of Berhaile (where they sell their salt before returning to the highlands), the trip takes an additional 8 days. It takes caravaners 4 days to travel from Berhaile to the salt flat and 4 days to return to Berhaile. This makes an extra round trip advantageous, because this part of the trip is short, and it enables caravaners to make a bit more profit before returning home.

\section{Lowland route}

The lowland portion of the salt route lies in the Afar region (Route 1) (Figure 8). Here, the highlanders follow a specific path, which passes through the lowland towns of Ab Ala, Korha, Darguni, Berhaile, Melabdi, Asa Bolo (Sabba), and Hamed Ela, before ending at the salt flat. Because the lowland caravaners live at many different desert localities along the trail in Zone Two, and join the highland caravaners at three major points (Berhaile, Asa Bolo (Sabba), and Hamed Ela), it usually takes them three to four days each way to travel to the salt flat. Lowland caravaners make more trips to the salt flat than highland caravaners, with most making 38 to 54 trips each year.

Evidence for the salt trail is provided by the presence of footpaths created by human and pack traffic carrying loads. The accumulation of animal bones, dung, and equipment used for pack travel on the trail, as well as the presence of modern and ancient caravan campsites alongside the trail, also provide useful evidence.

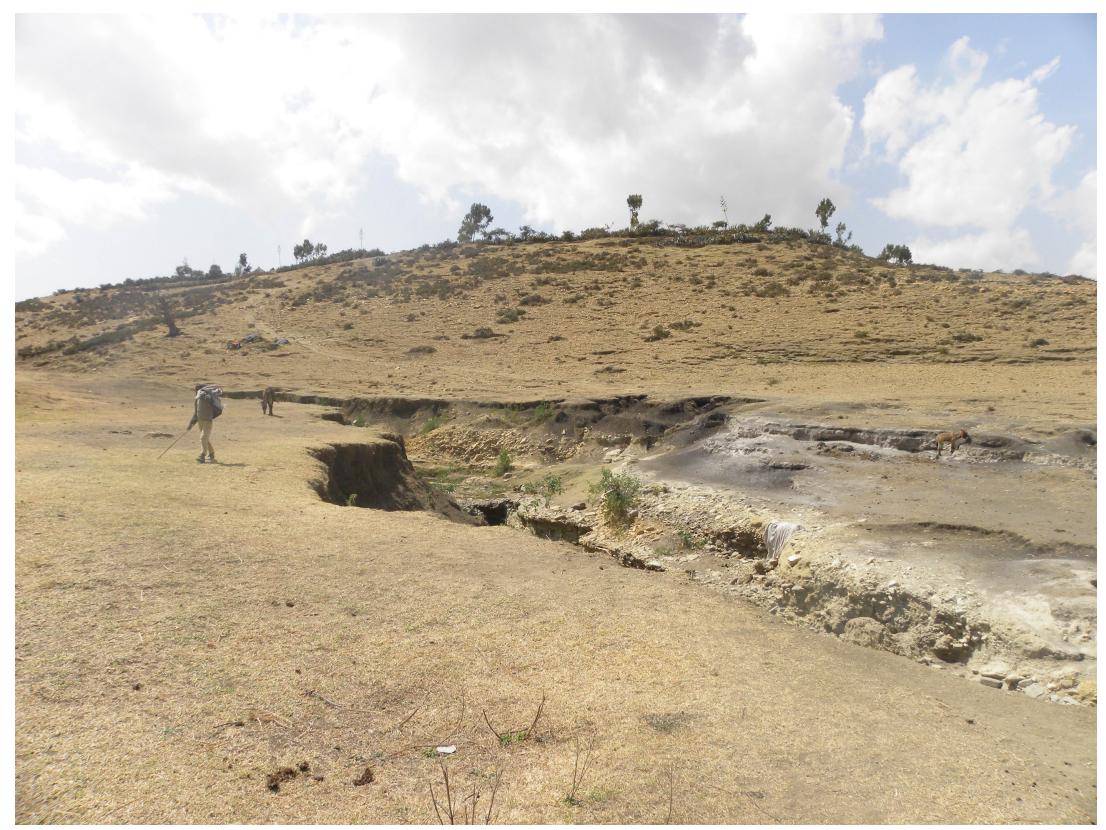

Figure 7. Highland trail near river stream. Photo by Woldekiros (2014).

Camino en las tierras altas cerca del cauce de un río. Fotografía de Woldekiros (2014). 


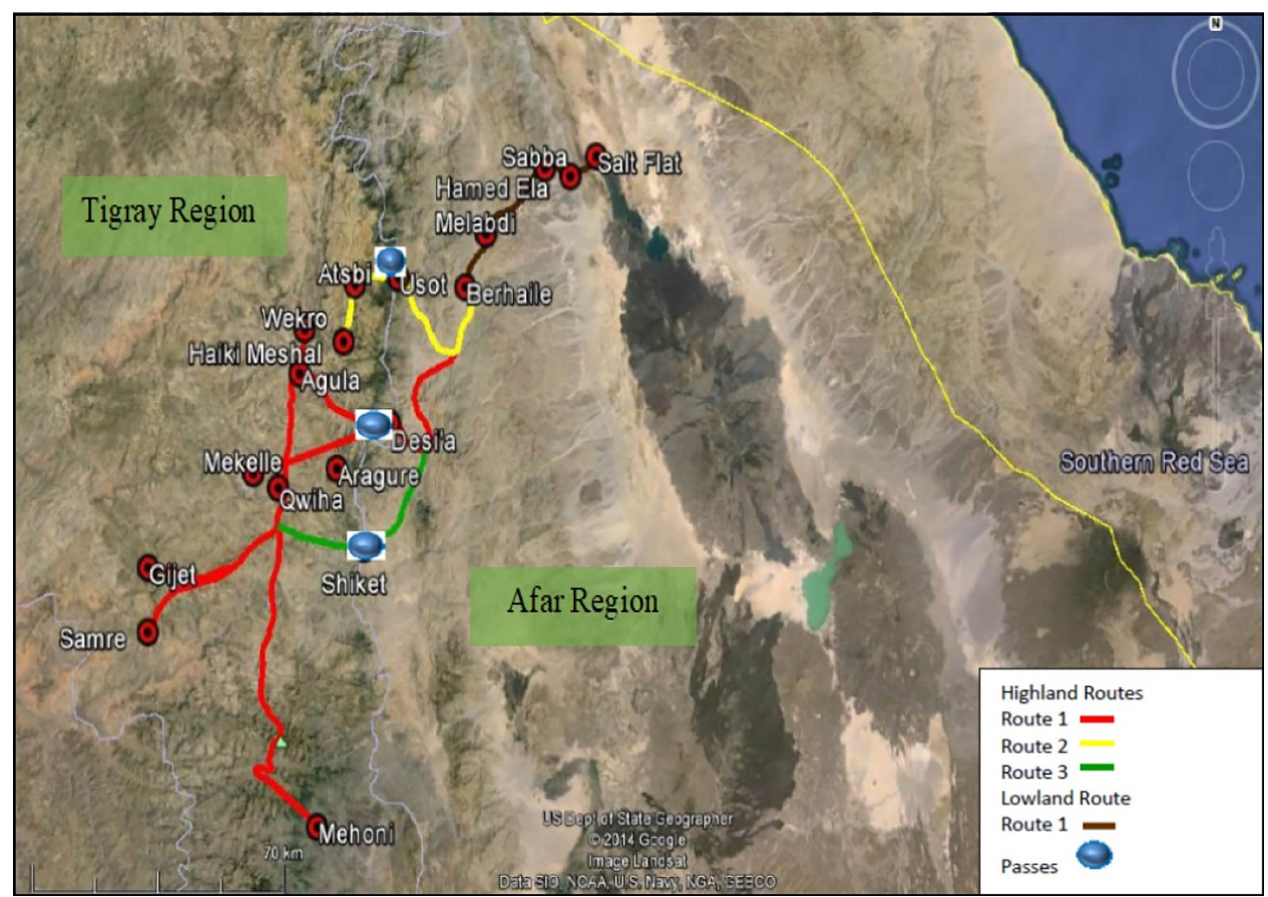

Figure 8. Map showing the four major caravan routes: the Usot, Desi'a and Shiket routes in the highland and the lowland route. Data from Woldekiros (2014).

Mapa de las cuatro rutas principales de caravanas: las rutas Usot, Desi'a y Shiket en la las tierras altas y la ruta en las tierras bajas. Datos de Woldekiros (2014).

\section{Ethnoarchaeology}

\section{Caravaner identity, gender, and economic status}

Caravaners come from the highland Tigray and lowland Afar regions, and all are men. Tigray caravaners stem from 11 villages in the highlands: Hagere Selam, Agula, Wekro, Desi'a, Usot, Haiki Meshail, Mekelle, Qwiha, Gijet, Samre, and Mehon. These caravaners are predominantly Christian farmers. The Afar caravaners, on the other hand, come from eight dispersed settlements in the Danakil Desert, near Aduka, Ab Ala, Lile, Berhaile, Melabdi, Asa Bolo, Hamed Ela and Koneba. Lowland caravaners are predominantly Muslim and speak a Cushitic language. These caravaners are mobile herders.

While Holocene archaeology for the Afar is lacking, archaeological research in the highlands indicates that pre-Aksumite villages, towns, cities, and permanent settlements were established in the North Ethiopian highlands by at least 3000 BP (D'Andrea et al. 2008). Today, Tigray settlements and villages are found on the tops of hills surrounding flood plains, and flat areas are used for farming. Pre-Aksumite and Aksumite settlements included floodplains and hills. The Afar, on the other hand, are mobile pastoralists in arid and semi- arid grasslands, although some are settled Afar herders residing south of the Danakil (Getachew 2001).

Both Afar and Tigray caravaners participate in the salt trade for the portion of the year when there is no highland farming or lowland seasonal mobility. Caravan villages from both regions send drovers in shifts, with a new group sent each time a group returns from the salt flat. This gives drovers time to rest, and it also supports equal economic opportunity in the village.

Both the Afar and the Tigray caravaners participate in the salt trade at a subsistence level, and do not make much profit. Mainly, they use their income from the trade to buy basic food supplies for their household. Moreover, most highland caravaners do not own their pack animals, but rent from other, more prosperous, farmers in their village. The salt trade is more profitable for the persons who rent out their pack animals than for those who participate in the trade. The trade is also more profitable for those who participate in forms other than caravan transport.

\section{Other participants}

In addition to caravaners, a range of stakeholders participate in the salt trade: warehouse owners, shop 
owners, water sack (sar) makers, coffee/tea vendors, residents, and salt producers. The role of caravaners ends once they unload salt at the first salt warehouses in the lowland portion of the salt trail.

Participation on the route, itself, is highly gendered, as all caravan members are men. However, this might not have always been the case, as there is mention of Emperor Menelik sending women and children to the salt flat in the $18^{\text {th }}$ century to mitigate conflict between Christian and Muslim caravaners (Pankhurst 1968). Water sack (sar) making, in contrast, is exclusively done by women. Sar made from goatskin is considered essential for caravaners, since it keeps water cool throughout the journey. Women also participate in the trade as shop and warehouse owners. The division of labor by gender and identity is also the norm at the salt flat, itself, where salt extraction is exclusively done by men. Tigray miners are responsible for digging the salt slab from the surface, which the Afar cut into three main forms or standard rock sizes: gole'o $(24 \times 36 \times 6 \mathrm{~cm})$, gerawayni $(23 \times 30 \times 6 \mathrm{~cm})$, and ankarabe $(22 \times 30$ $x 5 \mathrm{~cm}$ ). In the past, these standard sizes were used as currency.

\section{Caravan campsites}

Today, the rhythm of the trade requires caravaners to take two types of breaks during the journey: short breaks, lasting one to two hours; and long breaks, lasting four to six hours. Short-term resting places are chosen on the basis of the availability of water, grazing, and shade (i.e. from large acacia trees or rock shelters), and flat valleys with abundant vegetation are often preferred. Such sites are also strategically chosen to protect campfires from the desert wind. Long-term sites are usually used for overnight rest after a full day of travel (typically $20 \mathrm{~km}$, though the overnight campsites are not evenly dispersed along the route), with caravaners arriving at around 7:00pm and departing at around 3:00am the following morning. Such campsites are usually situated next to or outside of small farming villages in the highlands and small, permanent, pastoralist villages in the lowlands. These villages supply caravaners and pack animals with basic food and water, and provide protection from carnivore (jackal and fox) attacks and occasional raids from neighboring ethnic groups. The campsites tend to be large and may be occupied by as many as 700 to1,000 caravaners and 6,000 animals on any given night. Camping areas within the sites are allocated on a first come, first served basis.

Both long- and short-term campsites have distinctive structures. Furthermore, caravaners load/ unload and camp differently according to whether they are travelling to the salt flat or returning from the salt flat with cargo. Individual caravaners on their way to the salt flat organize campsites according to three major activity areas. The first area is used to corral camels, donkeys, and mules. Here, all pack animals sleep and eat, arranged in a circle with feed/hay piled in the center. The second area is where all pack saddles, water sacks, and animal feed are unloaded and stacked according to material type. Caravaners also sleep in this area, using pack saddles as mattresses or pillows. The third area is the hearth, where tea, coffee, and bread are made.

Caravaners use two types of hearths at the campsites: a hearth for tea and coffee and a hearth for bread. The tea and coffee hearth is made by creating a circle with three large semi-rectangular or circular rocks. The diameter of this hearth is usually between 15 and $25 \mathrm{~cm}$. The bread making hearth is much bigger and is characterized by an alignment of several small semi-round rocks that also functions as a griddle. This form of hearth is dictated by the bread making process for birkuta bread (round bread), which involves an open-air fire. This hearth is usually between 73 and $171 \mathrm{~cm}$ in diameter and is a very important part of the caravan camp.

Because 3,000 to 6,000 pack animals camp at the overnight rest areas, there are no proscribed east, west, north, or south directions in which activity areas are arranged. However, all hearth fires must be placed upwind of the camp, as a whole, as the Afar desert wind is very strong in the evenings. Between March and September, the wind blows to the south, and between September and March it blows east-west; this results in the varied placement of fires and other camp areas, according to the season.

Pack animals are usually tied to each other at overnight campsites, to prevent them from running away. It is only during the day, during short-term rests, that camels are let loose to graze by themselves. In the camps that are used on the way back from the salt flat, pack animals form a circle around the feed as usual, and the rock salt is piled up in two rows as it is unloaded from each animal. Caravaners take turns unloading the salt load and help each other in the loading/unloading process. In these camps, on the way back from the salt flat, caravaners set up their sleeping space to encircle both the pack animals and the salt pile. This is done to protect the animals and the salt load from any human danger, such as looting.

Several forms of material residue accumulate at caravan campsites, created by the caravaners and the pack animals. See Table 1 for the basic materials that modern caravaners from the highlands and lowlands usually carry.

\section{Archaeology}

Archaeological survey and excavation at two of the ancient caravan campsites, Meda Ble' at and Ona 
Table 1. Materials carried by modern highland and lowland caravaners.

Materiales transportados por caravaneros actuales de tierras altas y bajas.

\begin{tabular}{|c|c|c|c|}
\hline \multicolumn{2}{|c|}{ Food preparation } & \multirow{2}{*}{ Personal possessions } & \multirow{2}{*}{ Pack gear } \\
\hline Utensils & Food & & \\
\hline $\begin{array}{l}\text { - Metal, wooden, or plastic } \\
\text { bowl for mixing shiro with } \\
\text { bread crumbs and salt } \\
\text { - Spoon (metal or horn) } \\
\text { - Tea cup (plastic or gourd) } \\
\text { - Sand stone cobbles for } \\
\text { making bread } \\
\text { - Sorit for storing water } \\
\text { (sack made of goatskin) } \\
\text { - Madaberia (plastic or fiber } \\
\text { sack for storing flour) } \\
\text { - Knife (metal) } \\
\text { - Jerry can ( } 101 \text { or } 51) \\
\text { - Plastic or gourd jar }(11)\end{array}$ & $\begin{array}{l}\text { - Wheat, barley, or sorghum } \\
\text { flour to make bread (birkuta, } \\
\text { gogo) } \\
\text { - Shiro powder (spiced } \\
\text { chickpea and fava bean } \\
\text { powder used to make sauce) } \\
\text { - Sugar, tea, and coffee } \\
\text { - Hay for the herd: } \\
\text { - Chaf (te'f, wheat, barley) } \\
\text { from the highlands } \\
\text { - Wild grass from the low- } \\
\text { lands and highlands }\end{array}$ & $\begin{array}{l}\text { - Wooden comb } \\
\text { - Mefakia (wooden tooth brush) } \\
\text { - Gabi (cotton blanket for the } \\
\text { evening cold) } \\
\text { - Scarf to protect head from the } \\
\text { heat (wool) } \\
\text { - Shoes (sandals and flip flops } \\
\text { made of plastic or leather) } \\
\text { - Flashlight, D-cell batteries } \\
\text { - Knife for protection (e.g. } \\
\text { against foxes) } \\
\text { - Cloth shorts or wraparounds } \\
\text { - T-shirts and long-sleeved shirts } \\
\text { - Wooden stick for herding }\end{array}$ & $\begin{array}{l}\text { - Pack pads: gula and kuda (gula } \\
\text { are usually made of animal hide } \\
\text { and wool; kuda are made of cloth; } \\
\text { both are usually stuffed with } \\
\text { feathers or chaff to form cushions) } \\
\text { - Pack hooks: anabu, koree, } \\
\text { and koyeta (koree and koyeta } \\
\text { are vertical hooks; anabu are } \\
\text { horizontal; koyeta are used only } \\
\text { for salt loads, whereas koree are } \\
\text { used for both salt and other loads) } \\
\text { - Ropes and straps made of grass } \\
\text { fiber and leather to strap loads } \\
\text { on packs }\end{array}$ \\
\hline
\end{tabular}

Adi Abobay, provided data that illuminated the location and matrix of ancient caravan campsites along the Afar trade route. Ancient caravan campsites were located on floodplains, near water sources such as rivers and water wells, and the surface of these ancient caravan campsites were covered by lithic and ceramic scatter. The lithic material was mostly obsidian and chert flakes and debitage. The pottery sherds included red, gray, and brown ware dating to pre-Aksumite, Aksumite, and Medieval periods.

Excavation and analysis of the stratigraphy of Meda Ble'at and Ona Adi Abobay indicated that the depth of the ancient caravan campsites were typically very shallow, at 30 to $40 \mathrm{~cm}$ below the surface. Analysis of the stratigraphic layer of Meda Ble'at showed three major phases of sedimentation, each with a thickness of $10 \mathrm{~cm}$. The early phase (phase I) was culturally sterile, consisting of pebbly clay soil that was directly atop an ancient riverbed (about $40 \mathrm{~cm}$ below the surface), and 10 $\mathrm{cm}$ thick. About 80 percent of the inclusion was pebble. Phase II started at $10 \mathrm{~cm}$ below surface and was $20 \mathrm{~cm}$ thick. The silt and clay soil contained river pebbles and highly fragmented ceramic artifacts and lithic materials. The final —or later — phase of the site (phase III) was about $10 \mathrm{~cm}$ thick (Figure 9).

Excavation of Ona Abobay showed two major phases of site use. Phase I was the earliest phase for this site and was composed of dark gray clay soil that was very friable and compacted due to a high concentration of organic material. The matrix was darker than that of the later phase. The early phase was $20 \mathrm{~cm}$ thick and 14 $\mathrm{cm}$ below the surface. Phase I lay directly on top of the bedrock. Ceramics and obsidian artifacts were found all the way through, from the surface to the bedrock (Figure 10). Like site Meda Ble'at, Ona Adi Abobay demonstrated very low artifact density. Lithic artifacts at this site were mostly cores, unshaped tools, and angular waste, all made of chert. A few cereal grains were also recovered from this site, including wheat and barley.

In general, the ceramic dataset for the two caravan campsites was characterized by small ceramic body sherds with an average weight of 37 grams and a wall thickness ranging from 0.4 to $3 \mathrm{~cm}$. The ceramics from these caravan campsites were dominated by (circa) 5 th century AD Aksumite brown ware. There were, however, pre-Aksumite and Aksumite red, black, and gray wares in the assemblage. Some body sherds were decorated; most, however, were plain. Decorations included incisions in the form of horizontal bands, crisscrosses, and inverted 'V's.

\section{Discussion}

The Afar salt caravan project presented here provides the first systematic description of the Afar salt route in the Aksumite and Medieval periods. GPS points taken during the ethnographic study of the present-day caravan route confirm that modern caravaners still seek the best, least energetically costly route from the highlands to the lowland salt flat, based on slope steepness and water sources in the highland portion of the route. In the lowland portion, water sources and social factors are most important. Analysis of the results from the Tigray and Afar regions suggests that most of the modern and ancient footpaths are similar to the least-cost paths generated by GIS modeling. These paths pass through the pre-Aksumite, Aksumite, and Medieval sites and towns of Wekro, Quwiha, Atsbi, Agula, and Desi' a, suggesting that these towns might have been created as a result of the salt trade.

The least-cost paths also follow small, present-day pastoralist towns in the lowland portion of the route, 


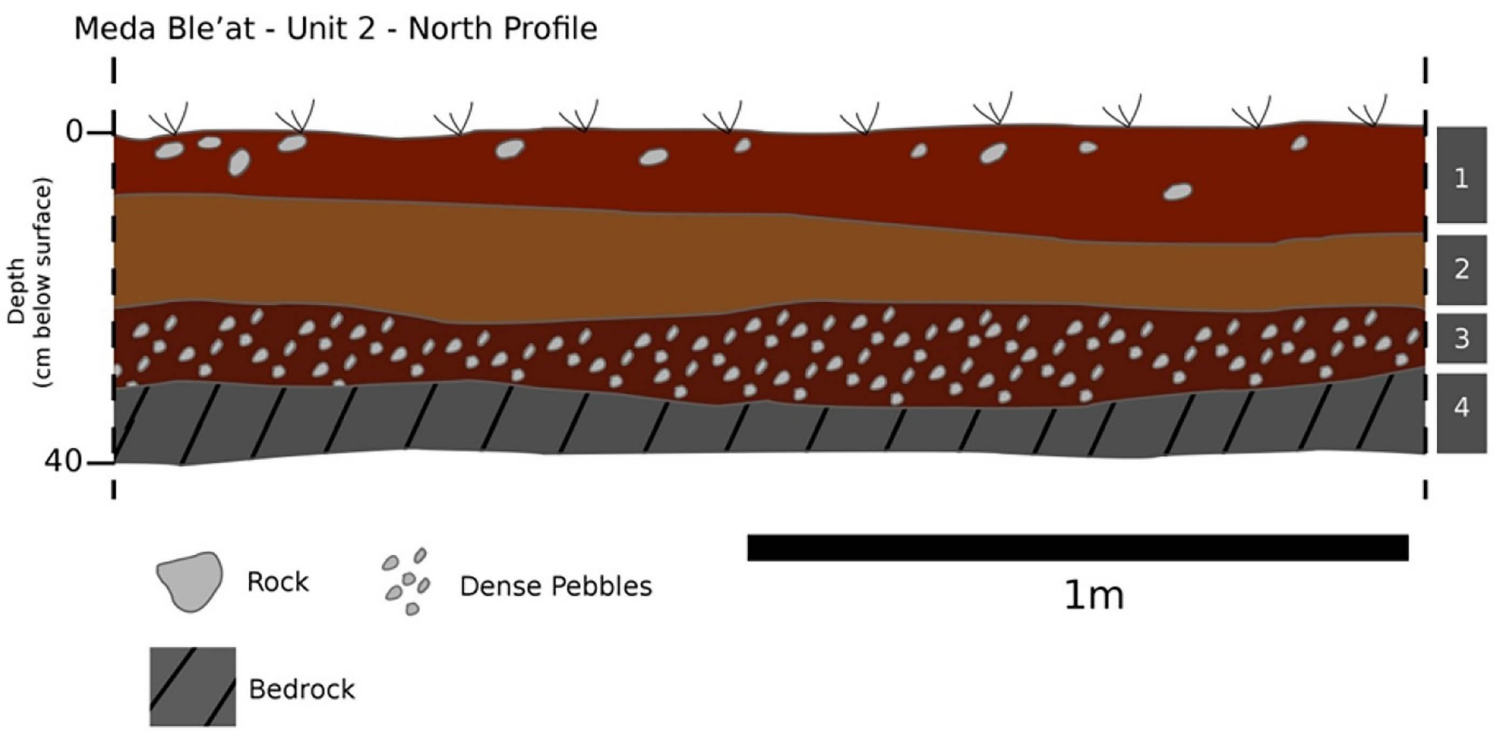

Figure 9. Stratigraphy profile of Meda Ble'at.

Perfil estratigráfico de Meda Ble'at.

Ona Abi Abobay - Unit 1 - West Profile

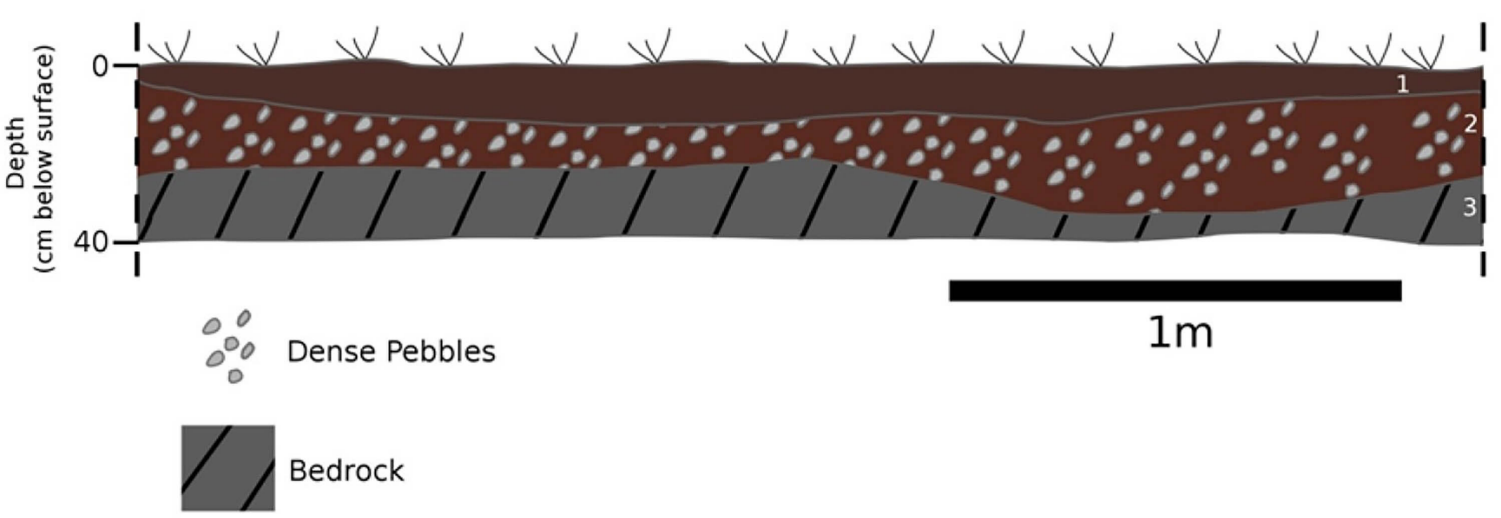

Figure 10. Stratigraphy profile of Site Ona Abobay.

Perfil estratigráfico del sitio Ona Abobay. 
showing the interrelatedness of the least-cost paths with settlements. The pastoralist settlements are also located near the best water sources in the Danakil Depression. The slopes selected by caravaners demonstrate very low to average elevation. The highland portion of the route is traveled at an elevation of 1,000 to $2,084 \mathrm{~m}$ above sea level. The length of the route that is suitable for pack caravan travel in the highlands is about 110 $\mathrm{km}$, extending from Mekelle to Desi'a. The length of the lowland portion of the route that is suitable for caravan travel is about $72 \mathrm{~km}$, with elevations ranging from $120 \mathrm{~m}$ below sea level to $658 \mathrm{~m}$ above sea level. The slope, aspect, elevation, and distance data suggest that, during the Aksumite period, caravan travel for local trade might have been optimized by minimizing costs through a particular choice of route rather than an effort to shorten overall distance. The long journey from the highlands to the lowlands would have put heavy constraints on logistics, had there not been collaboration between lowland pastoralist towns and highland traders. These social and political factors are very important variables that cannot be factored into the GIS analysis without ethnographic work. Finally, ethnographic data document that the majority of salt traders from the highlands originated from the Enderta district, which shows a high concentration of archaeological sites.

Few archaeological and anthropological studies have differentiated the behavior of caravans from that of other mobile groups, such as pastoralists (who also create sites with short-term and long-term activity signatures on the landscape). I argue that, while caravan campsites are distinctive, several lines of evidence must be used to trace ancient caravan activity. Such evidence should include not only the material correlates of caravan activity, but also those of the larger economic setting of caravan traders.

In contemporary North Ethiopia, caravans are exclusively used to transport salt, and everything that caravaners carry provides logistical support for the salt enterprise. The material that is incorporated into the archaeological record as a result of caravan activity relates to rest, camping, and salt transport, or is incorporated into the material record by accident. Caravaners leave residue when they prepare and purchase food and other supplies from settlements along the route, and material traces of these activities are left at every stop, through the process of loading and unloading packs. These activities, and their resultant residues, are likely to persist through time.

In contrast, ancient caravan activity shows large areas made up of many smaller campsites and shallow stratigraphy, consistent with repeated short-term occupation. Lithics and highly fragmented ceramics and dung indicate the presence of people and large numbers of livestock. However, the evidenced cuisine, emphasizing cereals and stone cooking on an open flame, is especially distinctive of caravaners, rather than pastoralists.
The excavated ceramic and lithic artifacts indicate that several groups of highland and lowland villagers participated in caravan trade as early as the Aksumite period. The ceramic assemblage provides particularly good proxy data on regional social identity.

\section{Conclusion}

The Aksumite state was among the most influential states between 400 BC-900 AD (Fattovich 2010; Munro-Hay 1991; Phillipson 2012) in and around the Red Sea area. To date, scholars have emphasized the role of long-distance trade and agriculture to the Aksumite economy. This research has generated new regionally contextualized methods for researching caravan transport and demonstrated how the salt trail from the Afar lowlands to the North Ethiopian highlands was used during the Aksumite period.

The Afar trail allows us to predict the existence of a salt trade between the lowlands and the highlands by at least 2000 BP. The organization of Aksumite salt trade might have been significantly different from its present form. However, the landscape-including mountain passes, slopes, water sources, and grazing areas-would have remained consistent over time. Mapping of the route and least-cost analysis demonstrates that travelers were not forced by instability or politics to avoid certain areas and were able to take the most direct routes. Further, the extreme effort required to travel the Afar salt route indicates that the relations between highlanders and lowland pastoralists were good enough to allow for trade and exchange during the Aksumite period. These aspects of the trail and its logistical requirements for both humans and animals enable us to build relational analogies and hypotheses to test in the archaeological record (sensu Wylie 2002). The Afar case study also provides insight for societies in other parts of the world with similar ecological and technological settings. In the Arabian Peninsula and in southwest Asia, for instance, ancient caravaners also used camels and donkeys to travel, carrying perishable commodities such as frankincense and spices. Ethnographic information on Afar travel logistics can be used to inform these cases.

This study of Afar salt route caravaners demonstrates the probable complexity of caravan routes and trade-offs between geographic constraints and social relationships, showing that Africa-especially sub-Saharan Africa-has great potential for enhancing our understanding of variability in the organization of complex ancient local and regional trade routes. Here, Ethiopia represents a particularly interesting case.

Acknowledgments: Archaeological and Ethnoarchaeological research was supported by the National Science Foundation doctoral dissertation research improvement grand BCS\#0939891, the 
Wenner-Gren Foundation for Anthropological Research Dissertation Fieldwork Grant \#8175, and the Fulbright Hays Doctoral Dissertation Research Abroad award 2010-2011. I want to thank Authority for Research and Conservation of Cultural Heritage, Addis Ababa, and Mr. Kebede Amare (Tigrai Culture and Tourism Agency, Mekelle). I want to also thank Ato Habtamu of Aksum University and his students for tirelessly accompanying me on survey and excavation in northern Ethiopia. Special thanks to the caravaners of northern Ethiopia for sharing their stories with me and for allowing me to take this incredible journey on the Afar trail, and the comments of the anonymous reviewers of Chungara.

\section{References Cited}

Alexianu, M. and O. Weller 2009. The Ethnosal Project. Ethnoarchaeological investigation at the Moldavian salt springs. Antiquity 83 (321).

Barrett-Gaines, K. 2004. The Katwe salt industry: A niche in the Great Lakes regional economy. African Economic History $32: 15-49$

Behrens, S. 1971. Physical Environment and its Significance for Economic Development, with Special Reference to Ethiopia. Lund, Sweden.

Berenguer, J. 2004. Caravanas, Interacción y Cambio en el Desierto de Atacama. Sirawi Ediciones, Santiago.

Biginagwa, T. J. 2012. Historical Archaeology of the 19th Century Caravan Trade in North-Eastern Tanzania: A Zooarchaeological Perspective. Doctoral Dissertation, Department of Anthropology, University of York, York.

Brigand, R. and O. Weller. 2015. Archaeology of Salt: Approaching an Invisible Past. Sidestone Press, Leiden.

Butzer, K. W. 1981. Rise and Fall of Axum, Ethiopia: A Geoarchaeological Interpretation. American Antiquity 46 (3):471-495.

Bonatti, E., C. Emiliani, G. Ostlund, and H. Rydell. 1971. Final Desiccation of the Afar Rift, Ethiopia. Science 172 (3982):468-69.

Clarkson, Persis B., C. M. Santoro, T. E. Levy, L. Núñez, A. Nielsen, S. Rosen, F. Förster, J.M. Capriles, A.M. Khazanov, M. Frachetti, D. Valenzuela, V.G. Standen, B. Cases, G. Pimentel, P. Lecoq, X. Medinacelli, L. Briones, A. Wink, N. Tripcevich, H. Riemer, E. O'Ryan, X. Loayza, T. Lynch, H. Woldekiros 2017. A worldwide network for comparative studies on caravans: past, present and future. Chungara Revista de Antropología Chilena 49 (3):297-307.

Connah, G., E. Kamuhangire and A. Piper 1990. Salt production at Kibiro. Azania: Archaeological Research in Africa 25 (1):2739.

Connah, G. 2001. African Civilizations: An Archaeological Perspective (2nd ed.). Cambridge University Press, Cambridge.

D’Andrea, A.C., A. Manzo, M.J. Harrower, and A.L. Hawkins 2008. The Pre-Aksumite and Aksumite Settlement of NE Tigrai, Ethiopia. Journal of Field Archaeology 33 (2):151-76.

EGS (Ethiopian Geologic Survey) 1973. Geology, Geochemistry and Hydrology of hot Springs of the East African Rift System within Ethiopia. United Nations, New York.

Falola, T. 1991. The Yoruba Caravan System of the Nineteenth Century. The International Journal of African Historical Studies 24 (1):111-132.

Fattovich, R. 2010. The development of ancient states in the northern Horn of Africa, c. 3000 BC-AD 1000: An archaeological outline. Journal of World Prehistory 23 (3):145-175.
Finneran, N. 2007. The Archaeology of Ethiopia. Routledge, London.

Förster, F. 2007. With donkeys, jars and water bags into the Libyan desert: the Abu Ballas Trail in the late Old Kingdom/ first Intermediate period. The British Museum, UK 7:1-35.

Förster, F. and H. Riemer (eds.) 2013. Desert road archaeology in ancient Egypt and beyond. Africa Praehistorica 27, HeinrichBarth-Institut, Köln.

Getachew, N.K. 2001. Among the Pastoral Afar in Ethiopia: Traditions, Continuity and Socio-Economic Change. International Books, In Association with OSSREA, Utrecht.

Good, C.M. 1972. Salt, trade, and disease: Aspects of development in Africa's northern Great Lakes region. International Journal of African Historical Studies 5 (4):543-586.

Harding, A. 2013. Salt in Prehistoric Europe. Sidestone Press, Leiden.

Harrower, M.J. and A.C. D'Andrea 2014. Landscapes of state formation: Geospatial analysis of Aksumite settlement patterns (Ethiopia). African Archaeological Review 31 (3):513-541.

Lovejoy, P.E. 1986. Salt of the Desert Sun: A History of Salt Production and Trade in the Central Sudan (vol. 46). Cambridge University Press, Cambridge.

Lyons, D. and A.C. D’Andrea. 2003. Griddles, ovens, and agricultural origins: An ethnoarchaeological study of bread baking in highland Ethiopia. American Anthropologist 105 (3):515-530.

McDougall, E.A. 1990. Salts of the Western Sahara: Myths, mysteries, and historical significance. International Journal of African Historical Studies 23 (2):231-257.

Mercuri, A.M., A.C. D’Andrea, R. Fornaciari and A. Höhn. 2018. Plants and People in the African Past: Progress in African Archaeobotany. Springer, Berlin/Heidelberg, Germany.

Munro-Hay, S.C. 2002. Ethiopia: The Unknown Land: A Cultural and Historical Guide. I. B. Tauris, London.

Munro-Hay, S.C. 1991. Aksum: An African civilisation of late antiquity. Edinburgh University Press, Edinburgh.

Nielsen, Axel. 2001. Ethnoarchaeological perspectives on caravan trade in the South-Central Andes. In: Kuznar, L.A. (Ed.), pp. 163201. Ethnoarchaeology of Andean South America. International Monographs in Prehistory, Ann Arbor.

Pankhurst, R. 1968. Economic History of Ethiopia, 1800-1935, pp. 92-93. Haile Sellassie I University Press, Addis Ababa.

Phillipson, D.W. 2000. Archaeology at Aksum, Ethiopia, 1993-97 (vol. 2). British Institute in Eastern Africa and Society of Antiquaries, London.

Phillipson, D.W. 2012. Foundations of an African Civilization: Aksum and the Northern Horn, 1000 BC-AD 1300. James Currey, Woodbridge.

Wilson, R.T. 1976. Some quantitative data on the Tigré salt trade from the early 19 th century to the present day. Annali. Istituto Orientale di Napoli 36 (2):157-164. 
Smith II, A.M. 2005. Pathways, roadways, and highways: networks of communication and exchange in Wadi Araba. Near Eastern Archaeology 68 (4):180.

Tripcevich, N. 2016. The ethnoarchaeology of a cotahuasi salt caravan: exploring Andean pastoralist movement. In The Archaeology of Andean Pastoralism, edited by J.M. Capriles and N. Tripcevich, pp. 211-230. The University of New Mexico Press, Albuquerque.

Tripcevich, N. 2008. Llama caravan transport: A study of mobility with a contemporary Andean salt caravan. In The "Nomads Anew" Symposium at the 73th Annual Meeting of the Society for American Archaeology, Vancouver, B.C., Canada. Available at: http://works.bepress.com/tripcevich/7.

Valenzuela, D., I. Cartajena, C.M. Santoro, V. Castro, and E.M. Gayo 2018. Andean Caravan Ceremonialism in the Lowlands of the Atacama Desert: The Cruces de Molinos Archaeological Site, Northern Chile. Quaternary International DOI: 10.1016/j.quaint.2018.09.016.
Williams, E. 1999. The ethnoarchaeology of salt production at Lake Cuitzeo, Michoacán, Mexico. Latin American Antiquity 10 (4):400-414.

Wilson, R.T. 1976. Some Quantitative Data on the Tigré Salt Trade from the Early 19th Century to the Present Day. Annali. Istituto Orientale Di Napoli 36 (2):157-270.

Woldekiros, H. 2014. The Afar Caravan Route: Insights into Aksumite (50 BCE-CE 900) Trade and Exchange from the Low Deserts to the North Ethiopian Plateau. Doctoral Dissertation, Department of Anthropology, Washington University in St. Louis.

Wolska-Conus, W. 1962. La Topographie Chrétienne de Cosmas Indicopleustès: Théologie et Science au VIe Siècle. Presses universitaires de France, Paris.

Wylie, A. 2002. Thinking from Things: Essays in the Philosophy of Archaeology. University of California Press, Berkeley. 